\title{
Examining the evidence for major histocompatibility complex-dependent mate selection in humans and nonhuman primates
}

This article was published in the following Dove Press journal:

Research and Reports in Biology

13 May 2015

Number of times this article has been viewed

\author{
Jamie CWinternitz ${ }^{1,2, *}$ \\ Jessica L Abbate Ab, $^{3, *}$ \\ 'Institute of Vertebrate Biology, \\ Czech Academy of Sciences, v.v.i, \\ Květná, Brno, Czech Republic; \\ ${ }^{2}$ Institute of Botany, Czech Academy \\ of Sciences, v.v.i, Lidická, Brno, Czech \\ Republic; ${ }^{3}$ Institute of Ecology and \\ Evolution, University of Bern, Bern, \\ Switzerland; ${ }^{4}$ INRA-UMR 1062 CBGP \\ (INRA, IRD, CIRAD, Montpellier \\ SupAgro), Montferrier-sur-Lez, \\ France \\ *These authors contributed equally to \\ this work
}

\begin{abstract}
Compounds of the major histocompatibility complex (MHC) are integral for effective vertebrate adaptive immune response, and are also implicated as cues for sexual selection. The evidence for this is supportive of MHC-based preference for diverse and dissimilar mating partners, in a range of vertebrates from fish to nonhuman primates. However, the evidence for a similar role of these genes and the evolutionary benefits of their diversity in human mate choice has been more controversial. Here, we review the results of 34 primary studies on MHC-mediated mate choice in humans and nonhuman primates in an effort to understand what processes may underscore, or belie, such differences. Both human and nonhuman primate studies show evidence of mate selection for MHC-dissimilarity and diversity, with fewer results in support of mate selection for optimal diversity or for specific "good gene". In general, stronger support comes from female-choice studies as opposed to male-choice studies (though male preferences and choice are investigated less often). This review suggests that the majority of mate choice results from contemporary human studies are consistent with our evolutionary history, but also reveals that only in humans do we find evidence for preference for mates with similar MHC composition. Overall, we show that contextual nuances, namely, population structure, multiple sensory cues that signal different information, and hormonal influences may explain the conflicting results observed for the role of MHC in human sexual preference, and argue for the exploration of such caveats in less well-studied systems to discern between general patterns and qualities unique to humans.
\end{abstract}

Keywords: major histocompatibility complex, sexual selection, olfaction, facial attraction, parasite resistance, inbreeding avoidance

\section{Introduction}

The role of the major histocompatibility complex (MHC) in mate selection has been investigated for almost 40 years with tantalizing results from both captive and wild populations in a diversity of systems including rodents, fish, birds, reptiles, and primates. ${ }^{1-5}$ While individual studies show a range of results, from no evidence to strong evidence for MHC-mediated mate choice, overall they proffer a general role for MHC diversity and dissimilarity in mate selection across vertebrates. ${ }^{6}$ In spite of relatively more effort placed on understanding the importance of $\mathrm{MHC}$ for human mating preferences, no such generalities have been distilled from human studies. Instead, excellent reviews have highlighted the equivocal and controversial nature of this topic. ${ }^{7,8}$

The difficulty in evaluating the role of $\mathrm{MHC}$ in mate choice across species is exacerbated by the differences in reproductive strategies between well-researched model species (eg, mice or sticklebacks that procreate early and abundantly) and humans
Correspondence: Jamie C Winternitz Research Facility Studenec, Institute of Vertebrate Biology, Czech Academy of Sciences 675 02, Studenec 122, Konesin 675 02, Czech Republic

Tel +420560590607

Fax +420568423 I2I

Email jcwinternitz@gmail.com 
(ie, live-slow-die-old strategy). To draw a clearer picture of what may influence patterns of MHC-mediated mate selection, it is worthwhile to re-evaluate the evidence across the primate order, comparing results from humans and nonhuman evolutionary siblings who share more life-history traits and reproductive strategies.

The goal of this review is to synthesize results from classic and contemporary studies of humans and other primates to consider human MHC-mediated mate selection from a primate perspective. We first provide a brief background of sexual selection theory and MHC biological functions, present the evidence for MHC-mediated mate selection in humans, and put those results into context using nonhuman primate studies. In so doing, we look for parallels among our own mating behaviors and those of our most recent ancestors in an effort to gain greater insight into the relationship between MHC diversity and dissimilarity, sexual selection, and offspring fitness. Finally, we discuss conclusions to be drawn from the available evidence and suggest research priorities for future investigations.

\section{Sexual selection theory and the MHC}

Darwin ${ }^{9}$ noticed that plumage, tails, and other exaggerated characters in male animals that should be detrimental to their survival, on the contrary, appeared to flourish with endless variety. He proposed that while these traits did not increase survival, they increased reproductive success by appealing to females. Sexual selection was thus considered an opposing force to natural selection, though more recent theories predict that they can reinforce one another. ${ }^{10}$ In a landmark paper, Hamilton and Zuk proposed that females may be selecting bright, showy males because these condition-dependent sexual characters indicate heritable genetic resistance to parasites. ${ }^{11}$ Parasites can have major impacts on fitness and can even determine host population dynamics, ${ }^{12,13}$ and animals that can detect and avoid mates likely to be parasitized would gain not only direct benefits 14,15 but also indirect benefits, or "good genes" for their offspring. ${ }^{16}$

The $\mathrm{MHC}$, an ancient chromosomal region found in virtually all vertebrates, is the perfect emblem of "good genes" as it is associated with immune defense and mating preferences in a wide array of species, including humans, mice, and nonmodel species. ${ }^{17-19}$ The MHC represents a set of loci that plays a role in presenting self and foreign particles to $\mathrm{T}$ lymphocytes, enabling nonself-recognition for immune activation. ${ }^{20,21} \mathrm{MHC}$ genes exist in a multigene family with two main subclasses, Class I and Class II, which are responsible for presenting antigenic peptides of intracellular and extracellular parasites, respectively. ${ }^{22}$ Genes within these classes are among the most polymorphic in the genome, and there is great variability in allelic diversity among loci (Figure 1). MHC alleles differ in their binding affinities for specific pathogen proteins (eg, binding supertypes) so that the degree of polymorphism at MHC loci is related to the variety of parasites recognized by the immune system. ${ }^{23}$ Among human populations, spatial patterns in MHC polymorphism have been explained in relation to both massive epidemics associated with human colonization and to regional parasite burdens, indicative of a strong role for parasites in shaping the microevolution of MHC. ${ }^{24}$ Individual MHC variability generates a selective advantage through enhanced clearance of and resistance to multiple infections. ${ }^{25,26}$ In addition, specific human MHC genotypes confer adaptive resistance to individual parasites, including malaria, hepatitis B, and HIV. ${ }^{27-29}$

Humans are often considered exempt from some of the processes acting on "natural" animal communities due to our ability to modify our environment and control the impact of potential selection events (eg, immunization, sanitation, quarantine, etc). ${ }^{30,31}$ Nevertheless, humans have interacted with parasites throughout our evolutionary history and are currently known to be infected by over 1,400 parasitic species. ${ }^{32,33}$ On a global scale, parasites are currently responsible for nearly 50 percent of mortality in humans under the age of $45 .^{34}$ Given the importance of parasites as selective pressure in natural systems, it follows that ubiquitous coevolving parasites should have played an equally powerful role in human biological evolution.

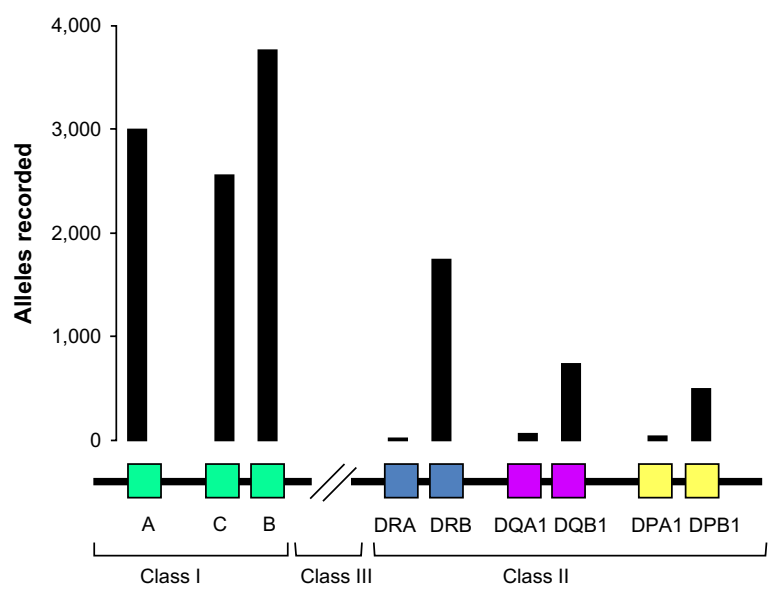

Figure I Simplified map of the human MHC showing the range of allelic diversity. Notes: The number of alleles encoded by the MHC of humans (HLA) is displayed above each locus. Allele numbers are from http://www.ebi.ac.uk/imgt/hla/stats.html (accessed January 2015).

Abbreviation: $\mathrm{MHC}$, major histocompatibility complex. 


\section{Role of MHC heterozygosity in mate selection and maintenance of fitness}

Due to its role in immune response, MHC polymorphism is attributed to antagonistic coevolution with parasites. Although it is clear that allelic diversity at MHC loci is associated with pathogens, ${ }^{24,35-39}$ other studies have pointed to disassortative mating and kin recognition, either for inbreeding avoidance or to increase offspring genetic diversity, in maintaining heterozygosity and allelic variation across the MHC. ${ }^{8,40-43}$ Simulation studies show that MHC-mediated sexual selection can effectively maintain polymorphism over a wide range of demographic scenarios,${ }^{44}$ and a comparative study across 117 mammal species indicated that a larger relative testes size (as a proxy for sexual selection) is universally associated with increased sequence diversity at a highly polymorphic Class II locus (DRB locus). ${ }^{45}$ In other words, there is both theoretical and cross-species support for the role of sexual selection in maintaining MHC diversity. Further, a number of studies have shown support for a direct mechanism allowing sexual selection on the MHC, including those focused on mice, fish, and humans that show animals can discern individuals with similar or dissimilar MHC genotypes based on olfactory cues. ${ }^{42,46-49}$ Allele-specific volatile byproducts of MHC-peptide binding are thought to be secreted in sweat and urine and these combinations reveal the allelic composition of the MHC genotype. ${ }^{41,50}$ Because of the possibility that some allele combinations are more beneficial than others under a given selection pressure, a condition-dependent selection mechanism could result in fitness advantage. However, it is not well understood how MHC-mediated cues for mate suitability impact fitness across changing selective landscapes. ${ }^{51}$

\section{Utility of MHC in mating preferences}

MHC-dependent mating preferences can fall under four nonmutually exclusive categories: ${ }^{52}$

1. Preference for dissimilar (or complementary) genotypes to increase offspring heterozygosity and thus increase their immunocompetence and reduce the probability of immunopathology from deleterious recessive alleles. In this case, highly polymorphic MHC loci may serve as indicators of genome-wide diversity and a preference for MHC dissimilarity could also assist with inbreeding avoidance in low-diversity populations.
2. Preference for intermediate dissimilarity - to obtain optimal rather than maximal diversity for offspring, ${ }^{53-56}$ providing enough protection from pathogens while also avoiding the cost of having too many alleles that present self-peptides and deplete autoreactive T-cell diversity. ${ }^{57}$ Here, as in (1), the preferred mate depends on the genotype of the chooser; in this instance, females with a low number of MHC alleles choose mates with more (dissimilar) alleles, and more diverse females choose males with fewer alleles. ${ }^{56,58}$

3. Preference for mates that possess a particular fitnessenhancing allele or supertype - to acquire direct benefits associated with high-quality mates and indirect benefits associated with heritable "good genes" for offspring. "Good genes" are predicted to be relatively rare in the population, stemming from the coevolutionary "arms race" with parasites. Specifically, parasite evolution is thought to drive the diversity of host MHC alleles in a negative-frequency dependent manner, leading to a time lag between a newly arisen MHC allele and widespread resistance. Hence, the most common alleles are predicted to be the most immunologically ineffective.

4. Preference for diverse (heterozygous) mates - to receive direct benefits associated with mates with better bodycondition (eg, higher intrasexual competitive ability, reduced risk of contracting infection, greater provisioning ability), or indirect benefits associated with "good-genesas heterozygosity" ${ }^{59,60}$ Theoretically, it has been shown that offspring of heterozygous males have higher relative fitness in fluctuating environments, and that female choice favoring heterozygous males is selected for under most scenarios. ${ }^{61}$ The preference for more heterozygous males may also be confounded with a preference for specific "good genes" or for similar genotypes, since more heterozygous individuals, on average, will harbor more rare alleles and will share more alleles. ${ }^{62,63}$

\section{Mate selection for MHC or inbreeding avoidance?}

There are significant fitness consequences of inbreeding, and examples in wildlife include lower birth weight, survival, reproduction, and resistance to disease. ${ }^{64}$ Mouse studies show mice shun mates with parental genotypes to avoid incestuous mating, ${ }^{65}$ suggesting that mice use MHC-associated cues primarily for inbreeding avoidance, rather than increasing immunogenetic diversity, per se ${ }^{42}$ on the other hand, experimentally controlled natural matings of red junglefowl (Gallus gallus) showed that $\mathrm{MHC}$, not background relatedness, 
drives female sperm use bias for MHC-dissimilar males. ${ }^{66}$ In humans and other primates, a greater risk of pregnancy failure is associated with high MHC similarity among mates. ${ }^{67-70}$ In addition, offspring conceived by MHC-similar spouses may be at greater risk for autoimmune disease associated with homozygosity. ${ }^{71}$

In addition to the consequences of inbreeding connected to $\mathrm{MHC}$ allele sharing between mates, partners sharing specific combinations of MHC alleles linked to killer immunoglobulin-like receptor (KIR) genes may be at greater risk for pregnancy disorders. KIRs are receptors expressed by natural killer cells and T cells that bind to MHC Class I glycoproteins expressed on all nucleated cells; these interactions activate or inhibit immune response to varying degrees, influencing susceptibility to and protection against infection and autoimmunity. ${ }^{72}$ Specific MHC-KIR combinations can result in excessive inhibition or activation of natural killer cells and influence pregnancy outcomes; in particular, KIR $A$ haplotypes lack genes that encode receptors for MHC-C2 ligands, which would normally help activate natural killer cells. ${ }^{73}$ This is important because the activation of natural killer cells helps form the placenta and enlarge maternal blood vessels, providing nourishment to the growing fetus. $^{72,74}$ Mothers homozygous for KIR $A$ have increased risk for preeclampsia, ${ }^{74-77}$ a condition during pregnancy characterized by endovascular abnormality that can develop into deadly seizures (eclampsia) and the main cause of pregnancy-related mortality worldwide. ${ }^{78}$ Suggestive evidence of selection against inhibitory combinations of MHC-KIR haplotypes comes from inverse frequencies of KIR $A$ haplotypes and MHC-C2 in a study conducted across 58 human populations. ${ }^{73}$ In effect, strong selection against hazardous maternal-fetal genotypes is driving the availability of those genotypes in space. Other evidence of coevolution between $M H C$ and KIR genes is related to their role in disease risk ${ }^{79,80}$ and the survival benefit conferred by these immune receptors may preserve their allelic diversity in spite of their reproductive disadvantage. ${ }^{72,80}$ Nonhuman primates and humans both have greater diversity at KIR genes than mice, suggesting a shared reliance on these genes for immune functioning that occurred relatively recently. ${ }^{72} \mathrm{MHC}-K I R$ combinations as well as epistatic interactions with other immunity-related genes $^{81}$ may be underlying the associations detected in primate MHC mate selection studies.

High costs of pregnancy make female mammals generally choosier about potential mates $;{ }^{82}$ in the case of humans, women tend to be more sexually cautious than men, ${ }^{83}$ but the goal of choosiness is still unclear. This is because mate selection for MHC diversity may be simply a by-product of preference for genome-wide diversity. In this case, $M H C$ genes may be acting as a marker for assessing relatedness between individuals, ${ }^{84}$ and recent genomic studies have shown that Nigerian Yoruban couples with high $\mathrm{MHC}$ similarity also have high genome-wide relatedness. ${ }^{85-88}$ This lack of independence between genomic regions can affect interpretations of the strength of MHC-mediated mate choice, and has only recently been examined. ${ }^{66}$ Nonhuman primate studies in the wild, obligated to rely on neutral markers for parentage assignment, have usefully incorporated both neutral and MHC relatedness to reveal significant relative importance of the $\mathrm{MHC}$ in mate selection. ${ }^{89,90}$

Related to the problem of linkage between MHC and genome-wide diversity within individuals is the complication of population structure. MHC allele frequencies vary across ethnic groups and populations, ${ }^{91,92}$ and selfpreference of subpopulations is characterized by distinctive frequencies of alleles. ${ }^{93}$ If the study subjects express racial or ethnic mate preferences that are correlated with $\mathrm{MHC}$ allele frequencies, then substructuring of alleles within a larger population may erroneously show selection for MHC similarity or dissimilarity. ${ }^{93,94}$ Most studies have acknowledged this caveat and have tried to control it by restricting their study population to individuals of similar ancestry. For example, homogeneous origins have been demarcated based on race (ie, skin color), ${ }^{95,96}$ and inferred from national or ethnic surnames. ${ }^{93,97,98}$ However, many human populations have substantial, yet not apparent, admixture, making it difficult to standardize samples. ${ }^{99-101}$ Further, preference for dissimilar or similar individuals may just as well be a real effect moderated by the diversity of the potential mate pool. The majority of studies finding MHC-dissimilarity preferences in humans and other primates that were statistically significant have used relatively homogenous and isolated populations. ${ }^{85,86,89,102}$ For example, the Hutterite population showing evidence for disassortative MHC mate choice in Ober et al's classic study descended from approximately 68 founders from the mid-1700s Russia. ${ }^{102}$ In contrast, studies finding preferences for MHC similarity have been conducted on more genetically variable populations or populations with strong sociocultural substructuring. ${ }^{54,93,103}$ Jacob et al suggested that when people are presented with choices among individuals with levels of MHC disparity that would typically be encountered in outbred, natural 
populations, they have a preference for mates with a greater number of shared $\mathrm{MHC}$ alleles to balance the competing costs of inbreeding and outbreeding. ${ }^{54}$

\section{Studies of mate preference cues in humans}

One of the most controversial issues regarding MHC-mediated preferences in humans is the mechanism of detecting genetic diversity in others. The specificity of MHC composition may be ascertained through the volatile peptides from urine, sweat, and axillary (armpit) glands, and as mentioned previously, there is increasing support from studies representing a variety of taxa that animals can identify MHC genotypes based on olfactory cues. ${ }^{42,46-49}$ The MHC-regulated differences in bacterial flora composition between individuals could allow for indirect association between MHC and body odors, ${ }^{104}$ perhaps where commensal microflora metabolize secreted MHC-peptide fragments and excrete them as volatile odors. ${ }^{41}$ Exciting recent evidence suggests that genetically determined microbial communities can influence scent marks of mice, ${ }^{105}$ and that more individual MHC Class II diversity is associated with less diverse gut microbiota in wild sticklebacks. ${ }^{106}$ This also highlights another potential reason to maintain optimal rather than maximal diversity - to preserve symbiotic microbiome diversity.

It is reasonable to ask if modern human practices such as wearing perfumes and hygienic routines make any historic MHC influence obsolete. ${ }^{97}$ Using 18 natural ingredients that have been in use as fragrances for over 5,000 years (eg, cinnamon, sandalwood, jasmine, and rose), Milinski and Wedekind experimentally tested the prediction that perfume preference for one's self is specific to MHC genotype. ${ }^{107}$ They found significant correlations between MHC genotype and perfumes selected "for self", but not "for partner", in line with the hypothesis that instead of disguising or masking natural body odor, perfumes may function to amplify MHC-related individual body odors. Interestingly, in a recent study, Milinski et al used artificially synthesized MHC-peptide ligands and a functional magnetic resonance imaging (fMRI) machine to test if humans possess the sensory facility to recognize MHC-associated olfactory cues. They found that female students preferred the scent of "self" to "nonself" peptides applied to their arms, and showed these preferences in brain activation scans, suggesting the presence of an internal reference for MHC genotype detection. ${ }^{108}$ This may help explain how humans can identify MHC-dissimilar mates.
In the first direct test of MHC-mediated odor preference in humans, Wedekind et al found MHC-dissimilar preferences in female Bern University students who were asked to rate the pleasantness of T-shirts worn two consecutive nights by male coeds. ${ }^{98}$ Not all odor-preference studies corroborate one another (Figure 2), and it has been suggested that variation in methodologies may explain the differences in their findings.? For example, the source of odor stimulus (T-shirts in contact with the majority axillary region vs cotton sachets in contact with the chest), treatment of the stimulus (same-day presentation to raters vs freezing and presentation weeks later), rating protocol and phrasing of survey questions, and number and identity of the MHC loci typed all may have nontrivial effects on the strength, if not direction, of the results. ${ }^{7}$

While odor is an important cue for female sexual preference, it is just one of multiple cues used to evaluate potential mates. ${ }^{109}$ An alternative or complementary mechanism for the relationship between $\mathrm{MHC}$ and mate choice in humans comes from female perception of male facial attractiveness. In a study of female mate choice, males who were heterozygous at three key MHC loci were judged as "more attractive" than males homozygous at single or multiple loci. ${ }^{96}$ Also, the skin of these males alone (in the absence of facial context) was judged as "healthier" than that of homozygotes. ${ }^{96}$ On a population level, the association between attractiveness and perceived immune status is manifested through an increased value on physical attractiveness in cultures exposed to high rates of parasitism. ${ }^{109}$ Data from 29 cultures show that areas with relatively higher pathogen prevalence value a mate's physical attractiveness more than people in areas with little pathogen incidence. ${ }^{109}$ The avoidance hypothesis supposes that individuals avoid mating with persons capable of spreading infection, ${ }^{110}$ and predicts that physical attractiveness may be a signal of current health and lack of transmissible parasite load. ${ }^{109}$ Alternatively, relative beauty may be an indication of mate quality and good genes, and sexual selection may discriminate individuals with regard to their pathogen resistance. ${ }^{111}$ For example, two features that are crossculturally associated with male attractiveness are prominent cheekbones and chins. ${ }^{112}$ As these traits develop during and after puberty in response to testosterone production ${ }^{113}$ and testosterone is an immunosuppressant, ${ }^{114}$ individuals who cannot afford the cost of a high level of testosterone production would display this honest advertisement of their gene quality in their facial features. Thus, facial attractiveness may be an honest indicator of "good genes" and preferences for good-gene indicator traits have been shown 


\section{A Human dissimilarity}

Facial preference

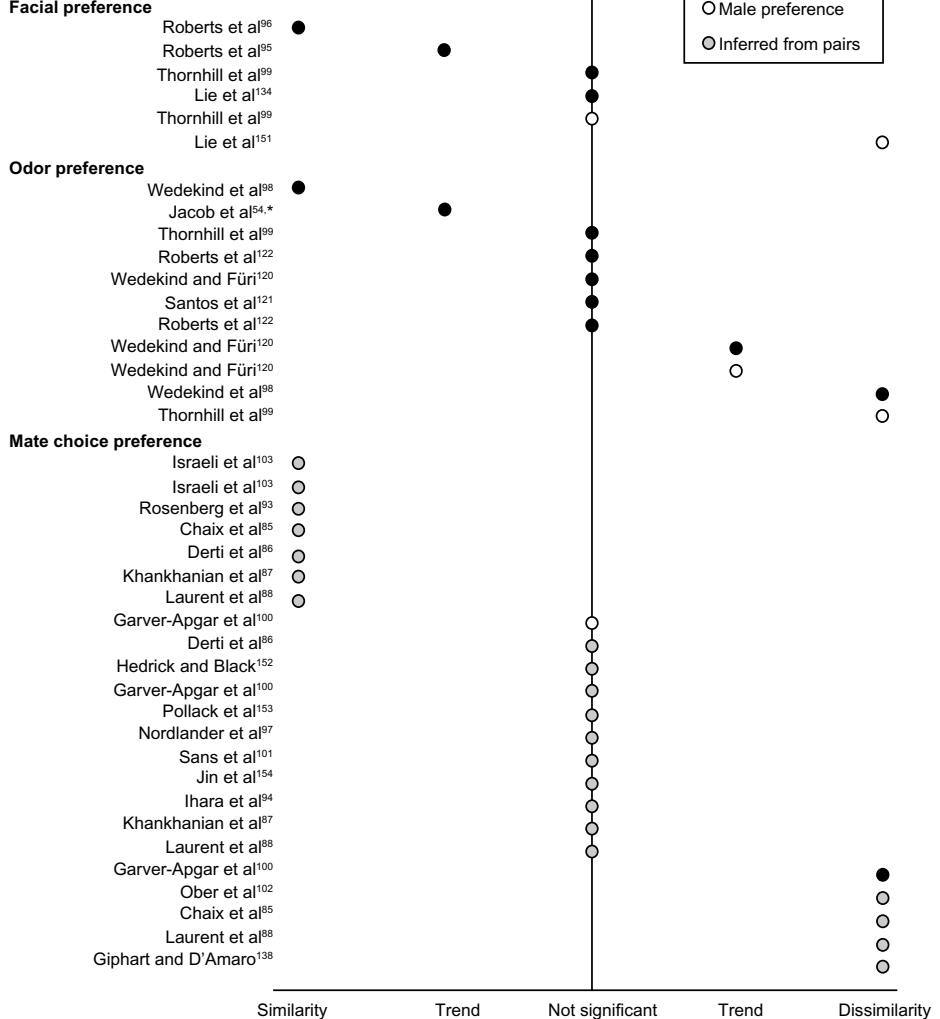

B Human diversity/heterozygosity

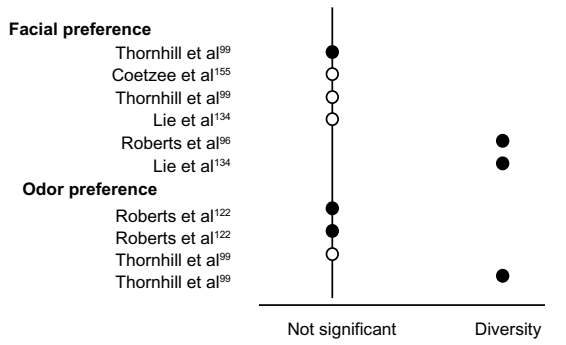

C Female pill use

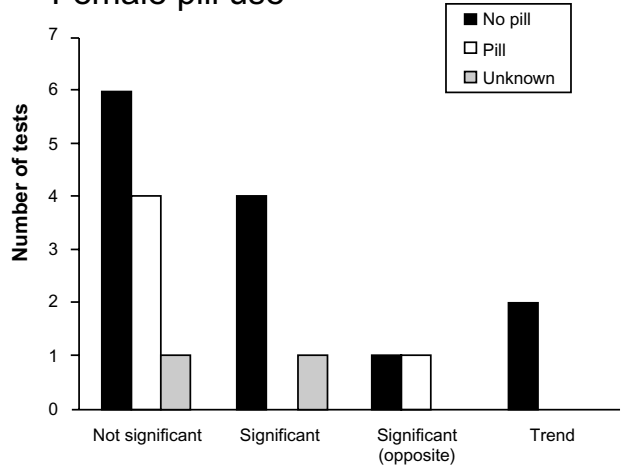

Figure 2 Summary of results for MHC-associated mate selection in humans.

Notes: Significant tests for preferences for (A) dissimilarity and (B) diversity and/or heterozygosity vary by the "chooser" investigated. Significance also varies within sex, and (C) shows the number of significant results (for both dissimilar and diversity preferences) according to women taking contraceptive pills and those normally cycling. The solid line in ( $\mathbf{A}$ and $\mathbf{B}$ ) denotes nonsignificant results. Trend refers to results with $P$-values between 0.05 and 0.1 . *Jacob et al's work ${ }^{54}$ supports a preference for an intermediate number of shared alleles. Data from the recent review by Havlíček and Roberts, ${ }^{7}$ and additional studies were identified up from 2008 to January 2015 via Web of Science using the topic "HLA" or "MHC" or "major histocompatibility complex" and "mate choice" or "mate selection" or "mate preference" and searching within results for "human".

Abbreviation: MHC, major histocompatibility complex.

to be relatively robust and consistent across cultures. ${ }^{115}$ Results so far have been inconclusive about the relative importance of sensory information on mating preferences, and multiple cues from different sensory modalities may be integrated for determining an optimal mate (Figure 3). For example, assortative preferences for facial similarity and disassortative preferences for odor may result in optimal degree of outbreeding. ${ }^{95,116}$

One explanation for the inconsistency in the strength and direction of odor and facial preference studies is variance in the context under which experiments were performed. Female primates (including humans) undergo periodic ovulation cycles with increased sexual behavior at midcycle, presumably in rhythm with ovulation. ${ }^{117}$ In naturally cycling women, changes occur in the concentration levels of several hormones, and these fluctuations are related to changes in women's attractiveness to men, as well as to women's sexual desire and motivation for sexual attention. ${ }^{118}$ It has been argued that females' estrous mate preferences

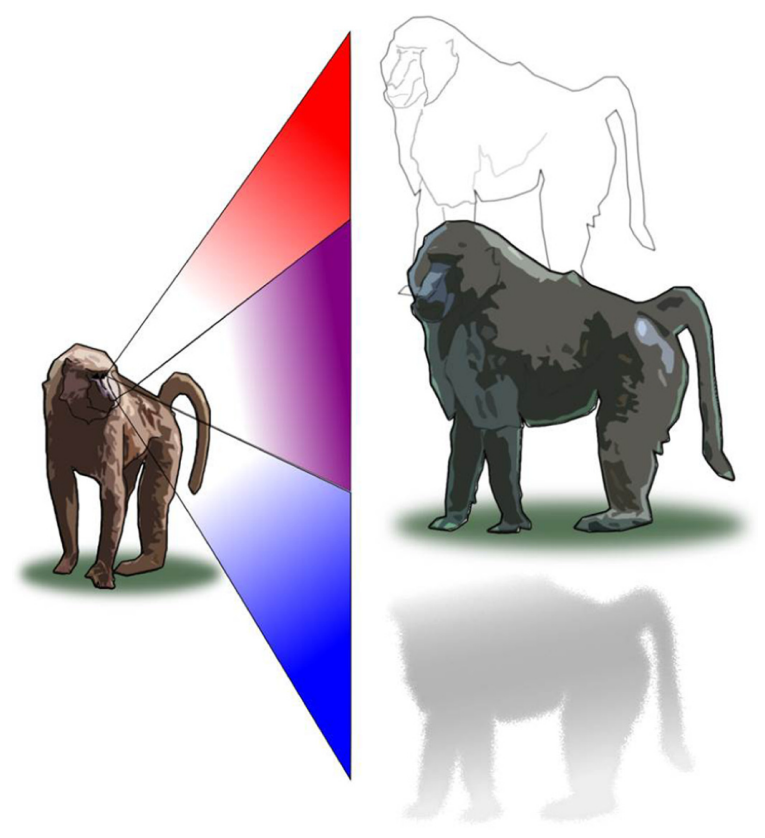

Figure 3 Information from multiple phenotypic cues (eg, visual and odor) may be integrated to inform mate preference. 
weigh cues and signals of intrinsic genetic benefits more heavily than outside the fertile phase. ${ }^{119}$ Interestingly (and perhaps disturbingly), Wedekind et al's study on olfactory preference among Bern University students found a reversed preference, for odors of MHC-similar men, in a subset of women who were taking contraceptive pills. ${ }^{98}$ Subsequent studies have found similar contrasting preferences between pill- and nonpill-using females, whereby in pill-users the predicted dissimilarity preference was either nonsignificant, or reversed (Figure 2C). ${ }^{120-122}$ Contraceptive pills (and other hormone-supplementation methods) developed to avoid pregnancy work in various biochemical ways to prevent either ovulation, fertilization, or implantation of an embryo; however, both the mechanism through which they act and the subsequent effects on female mood and sexuality is surprisingly poorly understood. ${ }^{123-126}$ These reviews also point out that there are intrinsic difficulties in the design of empirical studies on hormone effects on mate choice in humans, such as the fact that cross-sectional studies do not account for the under-representation of women who discontinue pill use after experiencing ill effects, rendering it difficult to confirm the pill's direct effects on female behavior. Some authors go so far as to argue that after confounding factors and appropriate response variables have been controlled, there remains no convincing evidence that the menstrual phase has any effect on the detection of mate genetic quality at all. ${ }^{126}$ Therefore, intra-individual preference consistency should be confirmed, and moderating factors should be investigated.

\section{Human vs nonhuman primate populations}

In common with many other primates, human females are thought to be sensitive to potential cues of indirect benefits. Strong selection for indirect benefits of mate choice typically occurs in polygynous and polyandrous mating systems, and there is evidence of a polygamous human heritage from comparative studies of sexual dimorphism ${ }^{127}$ and Y-chromosome diversity, ${ }^{128}$ reviewed by Roberts and Havlíček. ${ }^{129}$ Indeed, nonhuman primate studies are necessary to fully understand the evolution of MHC-mediated mate selection in humans because they allow us to track the evolutionary trajectory of the preference and to study the selective pressures favoring the traits' emergence and maintenance. ${ }^{67}$ Complementing similar behavioral traits, nonhuman primates share a number of genetic traits, including orthologous $M H C$ genes, with humans. ${ }^{130}$ Further, identical MHC allele motifs are associated with resistance to related pathogens, for example, to simian immunodeficiency virus (SIV), the predecessor of HIV. ${ }^{131}$

One difficulty with the study of human MHC-mediated mate choice is that current humans have ways of manipulating our microbiota, odor, and physical attributes, modifying signals of condition. Our relatively recent environmental modifications have dramatically increased human lifespan and health ${ }^{132}$ while at the same time increasing the difficulty for detecting evolutionary associations between mating preferences and fitness benefits. Our ancestral condition may be most closely reflected in remote tribes, like those of the Amazon that are chronically infected with marginally debilitating macroparasites like helminthes, transiently infected with bacteria (staphylococci, streptococci, diarrheal bacteria), and occasionally infected with endemic zoonotic diseases. ${ }^{32}$ However, the very thing that makes these populations so important to study, their relative isolation, is exactly what makes these population studies so challenging, namely, their inaccessibility. In lieu of observing our prehistoric ancestors, nonhuman primates can serve as a window to the past. Nonhuman primates are thought to represent human origins more closely than current human populations, and have potentially fewer confounding cultural, socioeconomic, and technological factors (eg, antibiotics, perfume, deodorants). Perhaps the most glaring example of our differences is the recent breakdown in limits to dispersal, facilitated by modern modes of travel. Whereas many prior criticisms have emphasized interracial/social influences on human assortative mating behavior, it is likely that the population structure of most wild or semi-wild primates more closely resembles that of our recent ancestors who only rarely dispersed over long distances. On the other hand, detecting selection for optimal MHC diversity may be difficult if the population is already at its equilibrium diversity optimum. ${ }^{133}$ Studying communities with a high proportion of disparate migrants (eg, college student studies ${ }^{98,100,122,134}$ ) may therefore offer some advantage along with the challenge of contemporary signal distortion.

\section{Results}

\section{Support for the specific functions of MHC-mediated mate choice}

We report here that the vast majority of the 34 primary studies on MHC-mediated mate choice in primates have focused on humans ( $\mathrm{n}=27)$, with just seven studies yet published on various other species including lemurs (Microcebus murinus and Cheirogaleus medius), rhesus macaques (Macaca mulatta), mandrill (Mandrillus sphinx), baboons (Papio ursinus), and 
the Sichuan snub-nosed monkey (Rhinopithecus roxellana) (Table S1). Nevertheless, several important patterns emerge from comparing results across these studies (Figures 2 and 4). One is that nearly half of all tests in both humans and nonhuman primates show a significant association between $\mathrm{MHC}$ genotype and mate selection. Another is that evidence for MHC-mediated mate preference is more often significant when tested in females than when tested in males or inferred from mating pairs. However, studies on female preference were twice as numerous as studies on male preference (human: 20 F, 9 M; nonhuman primates: 10 F, 5 M) (Table S1). This may reflect an expectation bias determining the allocation of study resources when preferences for indirect benefits, if observed at all, are predicted to be stronger for females and so easier to detect. Lastly, when evidence for each of the main hypotheses concerning MHC-involvement in sexual selection (listed below) has been lacking or conflicting, similar contextual factors present reasonable alternative hypotheses.

\section{Selection for similarity/dissimilarity among mates}

Tests of preference for more MHC-similar or dissimilar mates revealed approximately half of all studies with significant results showing strong evidence of selection for dissimilarity across humans and nonhuman primates (Figures 2A and 4A). In humans, men showed significant facial and odor preferences only for MHC-dissimilar women. ${ }^{99,134}$ Interestingly, several human studies also showed evidence of preference for MHC partner similarity, potentially reflecting assortative mating amongst widely mixed populations. Preferences for similarity included women's facial and odor preferences for MHC-similar men, ${ }^{95,96,98}$ and couples displaying more MHC-similarity than randomly assigned partners. ${ }^{54,85-88,93,103}$ However, excessive MHC-similarity may be undesirable and was shown to predict deviation from fidelity in both humans and other primates. Female fat-tailed dwarf lemurs
(Cheirogaleus medius) with extra-pair mates tended to have higher supertype overlap with their social mates than did females who did not have extra-pair copulations. ${ }^{5}$ Similarly for humans, women's stronger desire for extra-pair partners and sexual dissatisfaction with current mates was associated with more MHC allele overlap with those partners. ${ }^{100}$

\section{Selection for intermediate dissimilarity and diversity}

Evidence for optimal MHC-dissimilarity/diversity in mates is weak, though the majority of human and other primate studies have not explicitly tested for it. Two nonhuman primate studies tested for mate choice for optimal diversity and found nonsignificant results ${ }^{89,135}$ and two human studies found suggestive evidence of selection for optimal offspring diversity. Derti et al compared genome-wide single nucleotide polymorphisms (SNPs) between European-American mates and found some evidence that partners avoid extreme similarity at $M H C$ genes $^{86}$ (though another study using overlapping datasets have interpreted these results to support MHC-dissimilarity ${ }^{85,136}$ ); Jacob et al found that women preferred odors of men with more alleles matching those inherited paternally, but not maternally, ${ }^{54}$ suggesting that women employ an odor preference that provides them optimal allele matching.

\section{Selection for mates with greater MHC diversity}

Where an effect was detected, both humans and nonhuman primates universally showed preferences for MHC-indicating cues (in humans) or choice of actual mates (humans and other primates), signaling more diverse $\mathrm{MHC}$ haplotypes or supertypes than their own (or than other individuals in the population) (Figures 2B and 4B). 5,89,96,99,134,137 Additionally, this relationship has been detected solely as female preference for males. Similar findings were detected by Kamiya et al
A Nonhuman primate dissimilarity

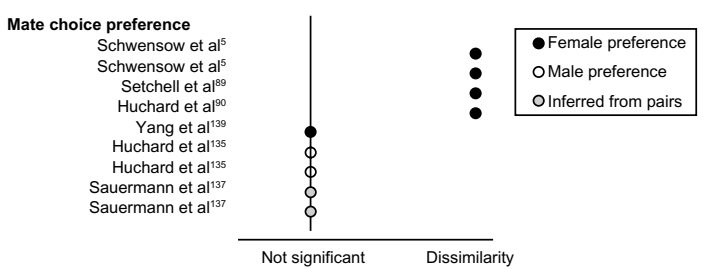

B Nonhuman primate diversity/heterozygosity

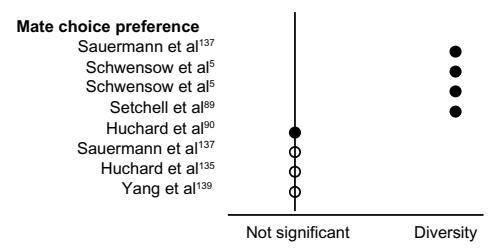

Figure 4 Summary of results for MHC-associated mate selection in nonhuman primates.

Notes: Significant tests for preferences for (A) dissimilarity and (B) diversity and/or heterozygosity vary by the "chooser" investigated. The solid line in (A) and (B) denotes nonsignificant results. Data from the recent review by Setchell and Huchard, ${ }^{67}$ and additional studies were identified up from 2009 to January 2015 via Web of Science using the topic "MHC" or "major histocompatibility complex" and "mate choice" or "mate selection" or "mate preference" and searching within results for "primate". Abbreviation: MHC, major histocompatibility complex. 
who recently conducted a meta-analysis across vertebrates and found evidence for diversity (and dissimilarity), but only when multiple loci within individuals were considered. ${ }^{6}$ This may indicate the presence of hotspots of selection on specific components of the $\mathrm{MHC}$, or that using more loci increases power to detect significant associations.

\section{Selection for "good genes"}

To date, there is only limited support for mate selection directed by "good genes" in humans and other primates. In a Dutch study, specific combinations of alleles had significantly increased frequencies in spouses than the background population, though preferential associations of disparate MHC alleles could not be distinguished from the linkage of alleles within haplotypes. ${ }^{138}$ Another study indicated selection for "good genes", although in this case, common alleles, rather than rare ones, predicted the attractiveness of women's scents to men. ${ }^{99}$ Rare alleles are expected to be advantaged in parasite defense, but as they are projected to increase in frequency until their commonness hinders their utility, allele frequency at any given time is a poor predictor of their current quality. In fat-tailed dwarf lemurs, specific MHC supertypes were more common in chosen social mates than random males, ${ }^{5}$ but three studies in other nonhuman primates found no evidence of selection for specific MHC supertypes. ${ }^{135,137,139}$ Additional investigations are needed to help resolve the generality of "good genes" preferences.

\section{Conclusion, caveats, and recommendations}

MHC-mediated mate choice in humans is a topic of great interest to biological, psychological, and social sciences, but is also highly controversial. ${ }^{86,136,140-146}$ In fact, of the 27 studies on human MHC-associated mate selection reviewed here, one-third (nine studies) have provoked direct criticism and published correspondence between authors and critics (Table S1). These discussions conclude that the most critical factor to consider is context, including within and among individuals and within and among populations. We briefly mention two caveats for the results of MHC-dependent mate selection studies. The first is that nonhuman primate studies have mostly focused on mate choice from pairs with one or more offspring and looked for differences between the pair components and the larger population; in contrast, many of the human studies were based on the mate preference of individual subjects for visual or olfactory cues. The eventual choice for a mate may be modified from the original preference by costs of choosiness (eg, from intersexual conflict or intrasexual competition). ${ }^{147}$

The second caveat is that mate choice inferred from paternity in studies may potentially be biased in favor of genetic dissimilarity if differential embryo mortality caused by $\mathrm{MHC}$ similarity and/or inbreeding restricts childless pairs from study. Only half of the human studies based on paired couples included any information on the presence of children, and all nonhuman primate pairs, which only found evidence for MHC-dissimilarity, were defined by the presence of at least one offspring. Yet a degree of preference for MHC similarity in human couples may reflect ancestry-related mate selection and not necessarily MHC-mediated selection. Studies that use many individuals and control for genome-wide effects to isolate $\mathrm{MHC}$-mediated mate selection will become more frequent as new methodologies (including large-scale $\mathrm{MHC}$ genotyping of nonmodel primate species and genome-wide SNP data) become more feasible. ${ }^{85-87}$

The intense scrutiny of the evidence concerning MHCmediated mate selection in humans can help serve as a guide for the design and interpretation of studies in other, particularly nonmodel, organisms. While many human behaviors can be argued as entirely "unnatural", they also highlight the importance of complicating factors (eg, hormone cycles and migration rates) that researchers of nonmodel species should be aware of within their own systems (eg, variance in social structure, population substructure, or population density), because they may influence the strength and direction of MHC-mediated mate selection, real or apparent. ${ }^{148}$ Perhaps the most salient take-home message from human studies is that MHC-associated mate selection differs between populations. Even setting aside the complications from sociocultural and economic conditions, human populations do show evidence for MHC-mediated mate selection, but the mode and direction of that selection are not consistent across populations. The variance in results can more adequately be delineated in a meta-analysis, and a clearer pattern of the drivers of differences in preference and choice await a quantitative comparison across studies.

In conclusion, we find that human studies are controversial with much debate over discordant results, but a thorough examination of findings from primate studies shows that this inconsistency is entirely consistent. The commonalities among the majority of human and nonhuman primate studies appear to be that the MHC is likely to be involved in mate-choice decisions for many populations, evidence for MHC-mediated mate selection is stronger for females than males, and the variation in results reflects issues surrounding 
multiple cues, population structure, and social influences. More generally, lack of evidence for mate preference or choice may reflect a greater cost than gain for expressing a preference, ${ }^{149}$ and search costs, opportunity costs, and tradeoffs with other preferences are dependent on context and demography. Greater exploration across nonhuman primate species with varying population and social structures, in addition to testing for preferences based on individual cues, will undoubtedly feed back into helping understand the relationship between MHC composition and sexual selection in humans.

\section{Acknowledgments}

We thank G Kergoat and two anonymous reviewers for helpful feedback on previous manuscript versions and M Hartfield and E Guivier for their assistance in hunting down all of the primary literature. This review was written with funding support for JCW from the European Social Fund (ESF) and the state budget of Czech Republic through the Operational Program Education for Competitiveness (OPEC), Reg No CZ.1.07/2.3.00/30.0048. Funding support for JLA came from the University of Berne.

\section{Disclosure}

The authors report no conflicts of interest in this work.

\section{References}

1. Yamazaki K, Boyse EA, Miké V, et al. Control of mating preferences in mice by genes in the major histocompatibility complex. J Exp Med. 1976;144(5):1324-1335.

2. Landry C, Garant D, Duchesne P, Bernatchez L. 'Good genes as heterozygosity': the major histocompatibility complex and mate choice in Atlantic salmon (Salmo salar). Proc R Soc Biol Sci Ser B. 2001;268(1473):1279-1285.

3. Olsson M, Madsen T, Nordby J, Wapstra E, Ujvari B, Wittsell H. Major histocompatibility complex and mate choice in sand lizards. Proc R Soc Biol Sci Ser B. 2003;270(Suppl 2):S254-S256.

4. Freeman-Gallant CR, Meguerdichian M, Wheelwright NT, Sollecito SV. Social pairing and female mating fidelity predicted by restriction fragment length polymorphism similarity at the major histocompatibility complex in a songbird. Mol Ecol. 2003;12(11):3077-3083.

5. Schwensow N, Fietz J, Dausmann K, Sommer S. MHC-associated mating strategies and the importance of overall genetic diversity in an obligate pair-living primate. Evol Ecol. 2008;22(5):617-636.

6. Kamiya T, O'Dwyer K, Westerdahl H, Senior A, Nakagawa S. A quantitative review of MHC-based mating preference: the role of diversity and dissimilarity. Mol Ecol. 2014;23(21):5151-5163.

7. Havlíček J, Roberts SC. MHC-correlated mate choice in humans: a review. Psychoneuroendocrinology. 2009;34(4):497-512.

8. Jordan WC, Bruford MW. New perspectives on mate choice and the MHC. Heredity. 1998;81(2):127-133.

9. Darwin C. Sexual Selection and the Descent of Man. London: Murray; 1871.

10. Andersson MB. Sexual Selection. Princeton NJ: Princeton University Press; 1994.

11. Hamilton WD, Zuk M. Heritable true fitness and bright birds: a role for parasites? Science. 1982;218(4570):384-387.
12. Hudson P, Rizzoli A, Grenfell B, Heesterbeek J, Dobson A. Ecology of Wildlife Diseases. Oxford: Oxford University Press; 2002.

13. Hudson PJ, Dobson AP, Newborn D. Prevention of population cycles by parasite removal. Science. 1998;282(5397):2256-2258.

14. Able DJ. The contagion indicator hypothesis for parasite-mediated sexual selection. Proc Natl Acad Sci U S A. 1996;93(5):2229-2233.

15. Loehle C. The pathogen transmission avoidance theory of sexual selection. Ecol Modell. 1997;103(2):231-250.

16. Pomiankowski A. The evolution of female mating preferences for male genetic quality. In: Harvey P, Partridge L, editors. Oxford Surveys in Evolutionary Biology. Oxford: Oxford University Press; 1988:136-184.

17. Potts WK, Wakeland EK. The maintenance of MHC polymorphism. Immunol Today. 1990;11(2):39-39.

18. Hedrick PW. Evolutionary genetics of the major histocompatibility complex. Am Nat. 1994;143(6):945-964.

19. Bernatchez L, Landry C. MHC studies in nonmodel vertebrates: what have we learned about natural selection in 15 years? J Evol Biol. 2003;16(3):363-377.

20. Hedrick PW, Kim TJ. Genetics of Complex Polymorphisms: Parasites and Maintenance of the Major Histocompatability Complex Variation. Cambridge: Cambridge University Press; 2000.

21. Hughes AL, Yeager M. Natural selection at major histocompatibility complex loci of vertebrates. Annu Rev Genet. 1998;32(1):415.

22. Knapp LA. The ABCs of MHC. Evol Anthropol. 2005;14(1):28-37.

23. Wegner K, Reusch T, Kalbe M. Multiple parasites are driving major histocompatibility complex polymorphism in the wild. J Evol Biol. 2003;16(2):224-232.

24. Prugnolle F, Manica A, Charpentier M, Guegan JF, Guernier V, Balloux F. Pathogen-driven selection and worldwide HLA class I diversity. Curr Biol. 2005;15(11):1022-1027.

25. Thursz MR, Thomas HC, Greenwood BM, Hill AV. Heterozygote advantage for HLA class-II type in hepatitis B virus infection. Nat Genet. 1997;17(1):11-12.

26. Penn DJ, Damjanovich K, Potts WK. MHC heterozygosity confers a selective advantage against multiple-strain infections. Proc Natl Acad Sci U S A. 2002;99(17):11260-11264.

27. Thursz MR, Kwiatkowski D, Allsopp CE, Greenwood BM, Thomas HC, Hill AV. Association between an MHC class II allele and clearance of hepatitis B virus in the Gambia. N Engl J Med. 1995;332(16): 1065-1069.

28. Trachtenberg E, Korber B, Sollars C, et al. Advantage of rare HLA supertype in HIV disease progression. Nat Med. 2003;9(7):928-935.

29. Hill AV, Allsopp CE, Kwiatkowski D, et al. Common West African HLA antigens are associated with protection from severe malaria. Nature. 1991;352(6336):595-600.

30. Christensen K, Vaupel JW. Determinants of longevity: genetic, environmental and medical factors. J Intern Med. 1996;240(6):333-341.

31. Vaupel JW. Biodemography of human ageing. Nature. 2010;464(7288): 536-542.

32. McMichael A. Human culture, ecological change, and infectious disease. Ecosyst Health. 2001;7(2):107-115.

33. Taylor LH, Latham SM, MarkE. Risk factors for human disease emergence. Philos Trans R Soc Lond B Biol Sci. 2001;356(1411):983-989.

34. Kapp C. WHO warns of microbial threat. Lancet. 1999;353(9171): 2222.

35. Gutierrez-Espeleta GA, Hedrick PW, Kalinowski ST, Garrigan D, Boyce WM. Is the decline of desert bighorn sheep from infectious disease the result of low MHC variation? Heredity. 2001;86:439-450.

36. Garrigan D, Hedrick P. Class I MHC polymorphism and evolution in endangered California Chinook and other Pacific salmon. Immunogenetics. 2001;53(6):483-489.

37. Goüy de Bellocq J, Charbonnel N, Morand S. Coevolutionary relationship between helminth diversity and MHC class II polymorphism in rodents. J Evol Biol. 2008;21(4):1144-1150.

38. Garamszegi LZ, Nunn CL. Parasite-mediated evolution of the functional part of the MHC in primates. J Evol Biol. 2011;24(1):184-195. 
39. Simkova A, Ottova E, Morand S. MHC variability, life-traits and parasite diversity of European cyprinid fish. Evol Ecol. 2006;20(5):465-477.

40. Brown JL, Eklund A. Kin recognition and the major histocompatibility complex: an integrative review. Am Nat. 1994;143:435-461.

41. Penn D, Potts W. How do major histocompatibility complex genes influence odor and mating preferences? Adv Immunol. 1998;69:411-436.

42. Potts WK, Manning CJ, Wakeland EK, Hughes AL. The role of infectious disease, inbreeding and mating preferences in maintaining $\mathrm{MHC}$ genetic diversity: an experimental test. Philos Trans R Soc Lond B Biol Sci. 1994;346(1317):369-378.

43. Hedrick PW. Female choice and variation in the major histocompatibility complex. Genetics. 1992;132(2):575-581.

44. Ejsmond MJ, Radwan J, Wilson AB. Sexual selection and the evolutionary dynamics of the major histocompatibility complex. Proc R Soc Biol Sci Ser B. 2014;281(1796):20141662.

45. Winternitz JC, Minchey SG, Garamszegi LZ, Huang S, Stephens PR, Altizer S. Sexual selection explains more functional variation in the mammalian major histocompatibility complex than parasitism. Proc $R$ Soc Biol Sci Ser B. 1769;2013:280.

46. Boyse EA, Beauchamp GK, Yamazaki K. The genetics of body scent Trends Genet. 1987;3(4):97-102.

47. Carroll LS, Penn DJ, Potts WK. Discrimination of MHC-derived odors by untrained mice is consistent with divergence in peptide-binding region residues. Proc Natl Acad Sci U S A. 2002;99(4):2187-2192.

48. Penn DJ. The scent of genetic compatibility: sexual selection and the major histocompatibility complex. Ethology. 2002;108(1):1.

49. Milinski M, Griffiths S, Wegner KM, Reusch TBH, Haas-Assenbaum A, Boehm T. Mate choice decisions of stickleback females predictably modified by MHC peptide ligands. Proc Natl Acad Sci U S A. 2005; 102(12):4414-4418.

50. Singer AG, Tsuchiya H, Wellington JL, Beauchamp GK, Yamazaki K. Chemistry of odortypes in mice: fractionation and bioassay. $J$ Chem Ecol. 1993;19(3):569-579.

51. Thompson JN. The Geographic Mosaic of Coevolution. Chicago, IL: University of Chicago Press; 2005.

52. Penn DJ, Potts WK. The evolution of mating preferences and major histocompatibility complex genes. Am Nat. 1999;153(2):145-164.

53. Milinski M. The function of mate choice in sticklebacks: optimizing MHC genetics. J Fish Biol. 2003;63:1-16.

54. Jacob S, McClintock MK, Zelano B, Ober C. Paternally inherited HLA alleles are associated with women's choice of male odor. Nat Genet. 2002;30(2):175-179.

55. Woelfing B, Traulsen A, Milinski M, Boehm T. Does intra-individual major histocompatibility complex diversity keep a golden mean? Philos Trans R Soc Lond B Biol Sci. 2009;364(1513):117-128.

56. Reusch TBH, Haberli MA, Aeschlimann PB, Milinski M. Female sticklebacks count alleles in a strategy of sexual selection explaining MHC polymorphism. Nature. 2001;414(6861):300-302.

57. Nowak MA, Tarczy-Hornoch K, Austyn JM. The optimal number of major histocompatibility complex molecules in an individual. Proc Natl Acad Sci U S A. 1992;89(22):10896-10899.

58. Aeschlimann P, Häberli M, Reusch T, Boehm T, Milinski M. Female sticklebacks Gasterosteus aculeatus use self-reference to optimize MHC allele number during mate selection. Behav Ecol Sociobiol. 2003;54(2):119-126.

59. Brown JL. A theory of mate choice based on heterozygosity. Behav Ecol. 1997;8(1):60-65.

60. Brown JL. The new heterozygosity theory of mate choice and the MHC. Genetica. 1999;104(3):215-221.

61. Charlesworth B. The evolution of mate choice in a fluctuating environment. J Theor Biol. 1988;130(2):191-204.

62. Apanius V, Penn D, Slev PR, Ruff LR, Potts WK. The nature of selection on the major histocompatibility complex. Crit Rev Immunol. 1997; 17(2):179-224.

63. Roberts SC, Hale ML, Petrie M. Correlations between heterozygosity and measures of genetic similarity: implications for understanding mate choice. J Evol Biol. 2006;19(2):558-569.
64. Keller LF, Waller DM. Inbreeding effects in wild populations. Trends Ecol Evol. 2002;17(5):230-241.

65. Yamazaki K, Beauchamp GK, Kupniewski D, Bard J, Thomas L, Boyse E. Familial imprinting determines H-2 selective mating preferences. Science. 1988;240(4857):1331-1332.

66. Løvlie H, Gillingham MAF, Worley K, Pizzari T, Richardson DS. Cryptic female choice favours sperm from major histocompatibility complex-dissimilar males. Proc R Soc Biol Sci Ser B. 1769;2013:280.

67. Setchell JM, Huchard E. The hidden benefits of sex: evidence for MHC-associated mate choice in primate societies. Bioessays. 2010; 32(11):940-948.

68. Knapp LA, Ha JC, Sackett GP. Parental MHC antigen sharing and pregnancy wastage in captive pigtailed macaques. J Reprod Immunol. 1996;32(1):73-88.

69. Ober C, Elias S, O’Brien E, Kostyu D, Hauck W, Bombard A. HLA sharing and fertility in Hutterite couples: evidence for prenatal selection against compatible fetuses. Am J Reprod Immunol Microbiol. 1988; 18(4):111.

70. Ober CL, Hauck WW, Kostyu DD, et al. Adverse effects of human leukocyte antigen-DR sharing on fertility: a cohort study in a human isolate. Fertil Steril. 1985;44(2):227-232.

71. Wilson AG, Symons JA, McDowell TL, McDevitt HO, Duff GW. Effects of a polymorphism in the human tumor necrosis factor $\alpha$ promoter on transcriptional activation. Proc Natl Acad Sci U S A. 1997; 94(7):3195-3199.

72. Parham P. MHC class I molecules and KIRs in human history, health and survival. Nat Rev Immunol. 2005;5(3):201-214.

73. Parham P, Guethlein LA. Pregnancy immunogenetics: NK cell education in the womb? J Clin Invest. 2010;120(11):3801-3804.

74. Hiby SE, Apps R, Sharkey AM, et al. Maternal activating KIRs protect against human reproductive failure mediated by fetal HLA-C2. J Clin Invest. 2010;120(11):4102-4110.

75. Varla-Leftherioti M, Keramitsoglou T, Parapanissiou E, et al. HLADQA $1 * 0505$ sharing and Killer Immunoglobulin-like Receptors in sub fertile couples: report from the 15th International Histocompatibility Workshop. Tissue Antigens. 2010;75(6):668-672.

76. Nowak I, Malinowski A, Tchórzewski H, et al. HLA-C C1C2 heterozygosity may protect women bearing the killer immunoglobulin-like receptor AA genotype from spontaneous abortion. J Reprod Immunol. 2011;88(1):32-37.

77. Ozturk OG, Sahın G, Karacor EDZ, Kucukgoz U. Evaluation of KIR genes in recurrent miscarriage. J Assist Reprod Genet. 2012;29(9): 933-938.

78. Duley L. The global impact of pre-eclampsia and eclampsia. Semin Perinatol. 2009;33(3):130-137.

79. Single RM, Martin MP, Gao X, et al. Global diversity and evidence for coevolution of KIR and HLA. Nat Genet. 2007;39(9):1114-1119.

80. Gendzekhadze K, Norman PJ, Abi-Rached L, et al. Co-evolution of KIR2DL3 with HLA-C in a human population retaining minimal essential diversity of KIR and HLA class I ligands. Proc Natl Acad Sci US A. 2009;106(44):18692-18697.

81. Traherne JA. Human MHC architecture and evolution: implications for disease association studies. Int J Immunogenet. 2008;35(3): 179-192.

82. Trivers R. Parental investment and sexual selection. In: Campbell B, editor. Sexual Selection and the Descent of Man. Chicago, IL: Aldine Publishing Company; 1972:136-179.

83. Buss DM, Schmitt DP. Sexual strategies theory: an evolutionary perspective on human mating. Psychol Rev. 1993;100(2):204.

84. Potts WK, Wakeland EK. Evolution of MHC genetic diversity: a tale of incest, pestilence and sexual preference. Trends Genet. 1993;9(12): $408-412$.

85. Chaix RL, Cao C, Donnelly P. Is mate choice in humans MHCdependent? PLoS Genet. 2008;4(9):e1000184.

86. Derti A, Cenik C, Kraft P, Roth FP. Absence of evidence for MHCdependent mate selection within HapMap populations. PLoS Genet. 2010;6(4):e1000925. 
87. Khankhanian P, Gourraud PA, Caillier SJ, et al. Genetic variation in the odorant receptors family 13 and the $\mathrm{MHC}$ loci influence mate selection in a multiple sclerosis dataset. BMC Genomics. 2010;11:626.

88. Laurent R, Toupance B, Chaix R. Non-random mate choice in humans: insights from a genome scan. Mol Ecol. 2012;21(3):587-596.

89. Setchell J, Charpentier M, Abbott K, Wickings E, Knapp L. Opposites attract: MHC-associated mate choice in a polygynous primate. $J$ Evol Biol. 2010;23(1):136-148.

90. Huchard E, Baniel A, Schliehe-Diecks S, Kappeler PM. MHCdisassortative mate choice and inbreeding avoidance in a solitary primate. Mol Ecol. 2013;22(15):4071-4086.

91. Cao K, Hollenbach J, Shi X, Shi W, Chopek M, Fernández-Viña MA. Analysis of the frequencies of HLA-A, B, and C alleles and haplotypes in the five major ethnic groups of the United States reveals high levels of diversity in these loci and contrasting distribution patterns in these populations. Hum Immunol. 2001;62(9):1009-1030.

92. Solberg OD, Mack SJ, Lancaster AK, et al. Balancing selection and heterogeneity across the classical human leukocyte antigen loci: a meta-analytic review of 497 population studies. Hum Immunol. 2008;69(7):443-464.

93. Rosenberg LT, Cooperman D, Payn R. HLA and mate selection. Immunogenetics. 1983;17(1):89-93.

94. Ihara Y, Aoki K, Tokunaga K, Takahashi K, Juji T. HLA and human mate choice: tests on Japanese couples. Anthropol Sci. 2000;108(2): 199-214.

95. Roberts SC, Little AC, Gosling LM, et al. MHC-assortative facial preferences in humans. Biol Lett. 2005;1(4):400-403.

96. Roberts SC, Little AC, Gosling LM, et al. MHC-heterozygosity and human facial attractiveness. Evol Hum Behav. 2005;26(3):213-226.

97. Nordlander C, Hammarström L, Lindblom B, Smith CE. No role of HLA in mate selection. Immunogenetics. 1983;18(4):429-431.

98. Wedekind C, Seebeck T, Bettens F, Paepke AJ. MHC-dependent mate preferences in humans. Proc R Soc Biol Sci Ser B. 1995;260(1359): 245-249.

99. Thornhill R, Gangestad SW, Miller R, Scheyd G, McCollough JK, Franklin M. Major histocompatibility complex genes, symmetry, and body scent attractiveness in men and women. Behav Ecol. 2003; 14(5):668-678.

100. Garver-Apgar CE, Gangestad SW, Thornhill R, Miller RD, Olp JJ. Major histocompatibility complex alleles, sexual responsivity, and unfaithfulness in romantic couples. Psychol Sci. 2006;17(10): 830-835.

101. Sans M, Alvarez I, Callegari-Jacques S, Salzano F. Genetic similarity and mate selection in Uruguay. J Biosoc Sci. 1994;26(03): 285-289.

102. Ober C, Weitkamp LR, Cox N, Dytch H, Kostyu D, Elias S. HLA and mate choice in humans. Am J Hum Genet. 1997;61(3):497-504.

103. Israeli M, Kristt D, Nardi Y, Klein T. Genetic considerations in human sex-mate selection: partners share human leukocyte antigen but not short-tandem-repeat identity markers. Am J Reprod Immunol. 2014;71(5):467-471.

104. Howard JC. H-2 and mating preferences. Nature. 1977;266(5601): 406-408.

105. Lanyon CV, Rushton SP, O'donnell AG, et al. Murine scent mark microbial communities are genetically determined. FEMS Microbiol Ecol. 2007;59(3):576-583.

106. Bolnick DI, Snowberg LK, Caporaso JG, Lauber C, Knight R, Stutz WE. Major histocompatibility complex class IIb polymorphism influences gut microbiota composition and diversity. Mol Ecol. 2014;23(19):4831-4845.

107. Milinski M, Wedekind C. Evidence for MHC-correlated perfume preferences in humans. Behav Ecol. 2001;12(2):140-149.

108. Milinski M, Croy I, Hummel T, Boehm T. Major histocompatibility complex peptide ligands as olfactory cues in human body odour assessment. Proc R Soc Biol Sci Ser B. 1755;2013:280.

109. Gangestad SW, Buss DM. Pathogen prevalence and human mate preferences. Ethol Sociobiol. 1993;14(2):89-96.
110. Hamilton WD, Axelrod R, Tanese R. Sexual reproduction as an adaptation to resist parasites a review. Proc Natl Acad Sci USA. 1990;87(9): 3566-3573.

111. Andersson M. Evolution of condition-dependent sex ornaments and mating preferences: sexual selection based on viability differences. Evolution. 1986;40:804-816.

112. Cunningham MR, Barbee AP, Pike CL. What do women want? Facialmetric assessment of multiple motives in the perception of male facial physical attractiveness. J Pers Soc Psychol. 1990;59(1):61.

113. Sherwood L. Human Physiology: From Cells to Systems. St Paul: West Publishing Company; 1989.

114. Alexander J, Stimson WH. Sex-hormones and the course of parasitic infection. Parasitol Today. 1988;4(7):189-193.

115. Roberts S, Little A. Good genes, complementary genes and human mate preferences. Genetica. 2008;132(3):309-321.

116. Bateson P. Sexual imprinting and optimal outbreeding. Nature. 1978;273:659-660.

117. Udry JR, Morris NM. Distribution of coitus in the menstrual cycle. Nature. 1968;220(5167):593-596.

118. Alvergne A, Lummaa V. Does the contraceptive pill alter mate choice in humans? Trends Ecol Evol. 2010;25(3):171-179.

119. Gangestad SW, Thornhill R. Menstrual cycle variation in women's preferences for the scent of symmetrical men. Proc R Soc Biol Sci Ser B. 1998;265(1399):927-933.

120. Wedekind C, Füri S. Body odour preferences in men and women: do they aim for specific MHC combinations or simply heterozygosity? Proc R Soc Biol Sci Ser B. 1997;264(1387):1471-1479.

121. Santos PSC, Schinemann JA, Gabardo J, da Graça Bicalho M. New evidence that the MHC influences odor perception in humans: a study with 58 Southern Brazilian students. Horm Behav. 2005;47(4):384-388.

122. Roberts SC, Gosling LM, Carter V, Petrie M. MHC-correlated odour preferences in humans and the use of oral contraceptives. Proc $R$ Soc Biol Sci Ser B. 2008;275(1652):2715-2722.

123. Burrows LJ, Basha M, Goldstein AT. The effects of hormonal contraceptives on female sexuality: a review. J Sex Med. 2012;9(9): 2213-2223.

124. Graham CA, Bancroft J. Oral contraceptives and women's sexuality: commentary on Roberts, Cobey, Klapilová, and Havlíček (2013). Arch Sex Behav. 2013;42(8):1377-1378.

125. Roberts SC, Cobey KD, Klapilová K, Havlíček J. An evolutionary approach offers a fresh perspective on the relationship between oral contraception and sexual desire. Arch Sex Behav. 2013;42(8): 1369-1375.

126. Wood W, Carden L. Elusiveness of menstrual cycle effects on mate preferences: comment on Gildersleeve, Haselton, and Fales (2014). Psychol Bull. 2014;140(5):1265-1271.

127. Harcourt AH, Harvey PH, Larson SG, Short RV. Testis weight, body weight and breeding system in primates. Nature. 1981;293(5827): 55-57.

128. Dupanloup I, Pereira L, Bertorelle G, et al. A recent shift from polygyny to monogamy in humans is suggested by the analysis of worldwide Y-chromosome diversity. J Mol Evol. 2003;57(1):85-97.

129. Roberts SC, Havlíček J. Humans are dunnocks, not peacocks: on cause and consequence of variation in human mating strategies. Psychol Inq. 2013;24(3):231-236.

130. Bontrop RE. Comparative genetics of MHC polymorphisms in different primate species: duplications and deletions. Hum Immunol. 2006;67(6):388-397.

131. Bontrop RE, Watkins DI. MHC polymorphism: AIDS susceptibility in non-human primates. Trends Immunol. 2005;26(4):227-233.

132. Burger O, Baudisch A, Vaupel JW. Human mortality improvement in evolutionary context. Proc Natl Acad Sci U S A. 2012;109(44): 18210-18214.

133. Tregenza T, Wedell N. Genetic compatibility, mate choice and patterns of parentage: invited review. Mol Ecol. 2000;9(8):1013-1027.

134. Lie HC, Rhodes G, Simmons LW. Genetic diversity revealed in human faces. Evolution. 2008;62(10):2473-2486. 
135. Huchard E, Knapp LA, Wang J, Raymond M, Cowlishaw G. MHC, mate choice and heterozygote advantage in a wild social primate. Mol Ecol. 2010;19(12):2545-2561.

136. Laurent R, Chaix R. MHC-dependent mate choice in humans: why genomic patterns from the HapMap European American dataset support the hypothesis. Bioessays. 2012;34(4):267-271.

137. Sauermann U, Nürnberg P, Bercovitch FB, et al. Increased reproductive success of MHC class II heterozygous males among free-ranging rhesus macaques. Hum Genet. 2001;108(3):249-254.

138. Giphart M, D'Amaro J. HLA and reproduction? J Immunogenet. 1983;10(1):25-29.

139. Yang B, Ren B, Xiang Z, et al. Major histocompatibility complex and mate choice in the polygynous primate: the Sichuan snub-nosed monkey (Rhinopithecus roxellana). Integr Zool. 2014;9(5):598-612.

140. Gill T 3rd. HLA and mate choice. Am J Hum Genet. 1998;62(4) 985.

141. Weitkamp LR, Ober C. Reply to gill. Am J Hum Genet. 1998;62(4): 986-987.

142. Beauchamp GK, Yamazaki K. HLA and mate selection in humans: commentary. Am J Hum Genet. 1997;61(3):494

143. Hedrick P, Loeschcke V, Boero F. MHC and mate selection in humans? Trends Ecol Evol. 1996;11(1):24.

144. Wedekind C, Seebeck T. MHC and mate selection in humans? Reply Trends Ecol Evol. 1996;11(1):24-25.

145. Wedekind C. The MHC and body odors: arbitrary effects caused by shifts of mean pleasantness. Nat Genet. 2002;31(3):237-237.

146. McClintock MK, Schumm P, Jacob S, Zelano B, Ober C. The MHC and body odors: arbitrary effects caused by shifts of mean pleasantness. Nat Genet. 2002;31(3):237-238.
147. Jennions MD, Petrie M. Variation in mate choice and mating preferences: a review of causes and consequences. Biol Rev. 1997; 72(2):283-327.

148. Tybur JM, Gangestad SW. Mate preferences and infectious disease: theoretical considerations and evidence in humans. Philos Trans $R$ Soc Lond B Biol Sci. 2011;366(1583):3375-3388.

149. Kokko H, Jennions MD, Brooks R. Unifying and testing models of sexual selection. Annu Rev Ecol Evol Syst. 2006;37:43-66.

150. Trowsdale J. The MHC, disease and selection. Immunol Lett. 2011; 137:1-8.

151. Lie HC, Simmons LW, Rhodes G. Genetic dissimilarity, genetic diversity, and mate preferences in humans. Evol Hum Behav. 2010;31(1):48-58.

152. Hedrick PW, Black FL. HLA and mate selection: no evidence in South Amerindians. Am J Hum Genet. 1997;61(3):505-511.

153. Pollack MS, Wysocki CJ, Beauchamp GK, Braun D Jr, Callaway C, Dupont B. Absence of HLA association or linkage for variations in sensitivity to the odor of androstenone. Immunogenetics. 1982;15(6): 579-589

154. Jin K, Speed T, Thomson G. Tests of random mating for a highly polymorphic locus: application to HLA data. Biometrics. 1995: 1064-1076.

155. Coetzee V, Barrett L, Greeff JM, Henzi SP, Perrett DI, Wadee AA. Common HLA alleles associated with health, but not with facial attractiveness. PLoS ONE. 2007;2(7):e640. 


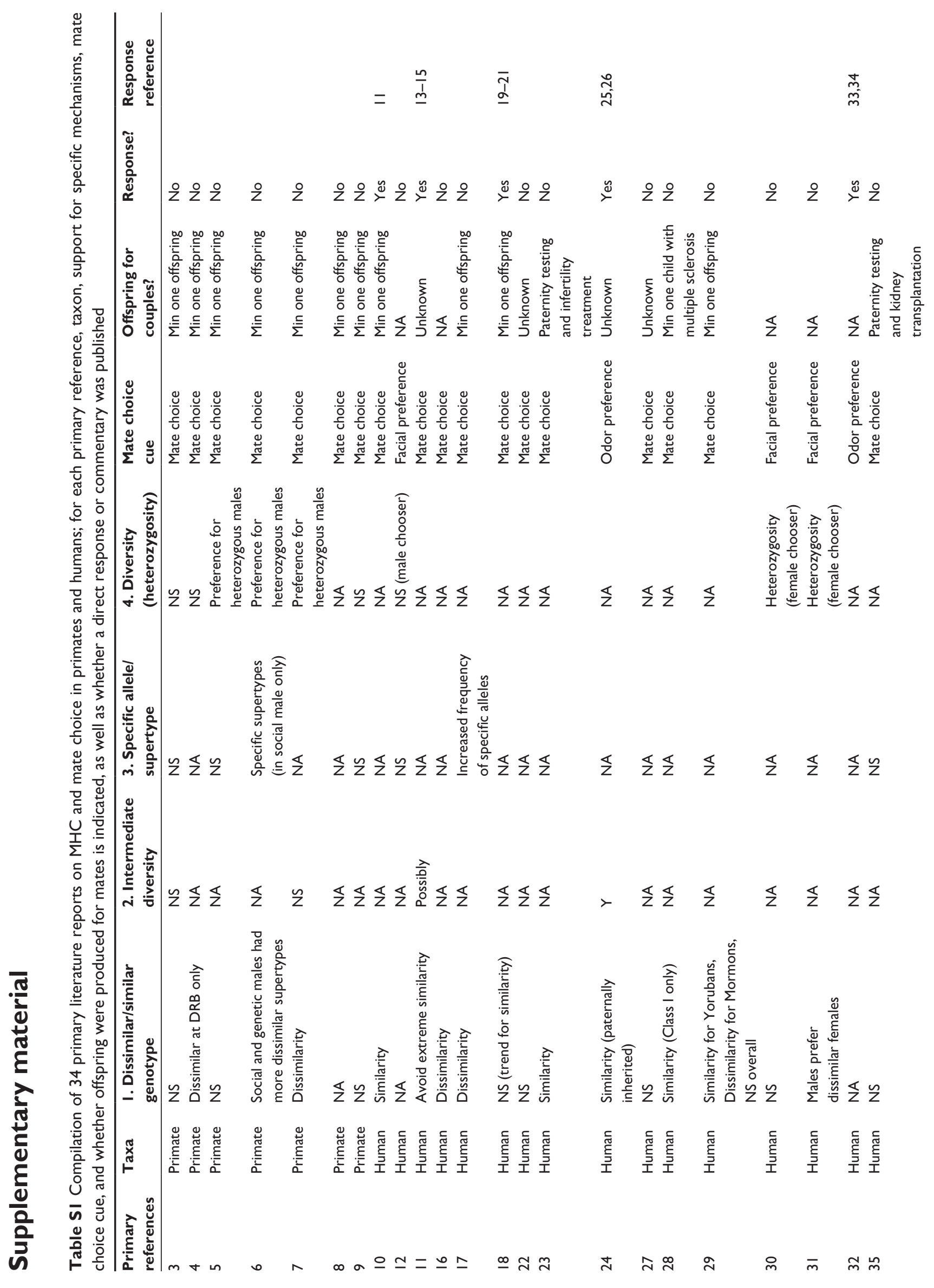




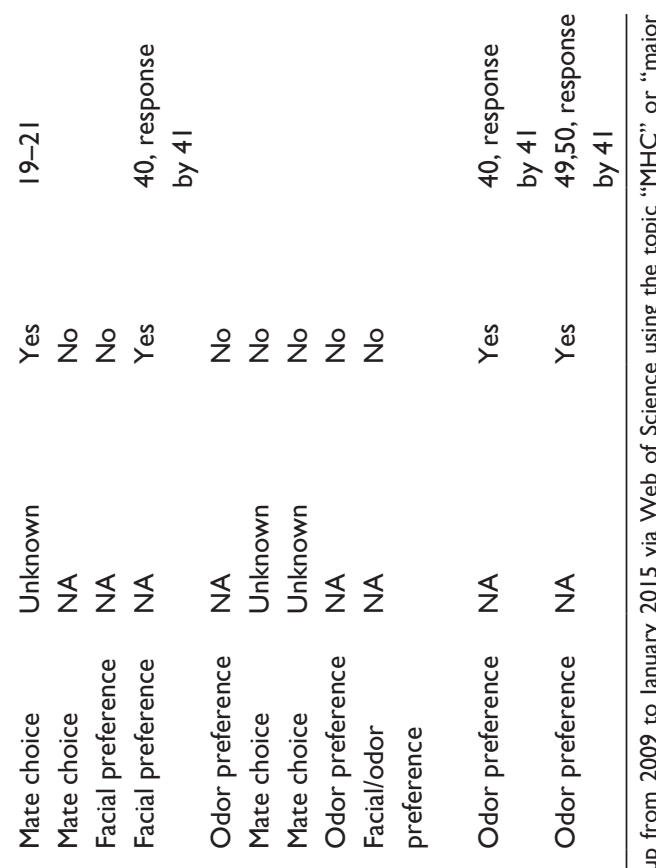

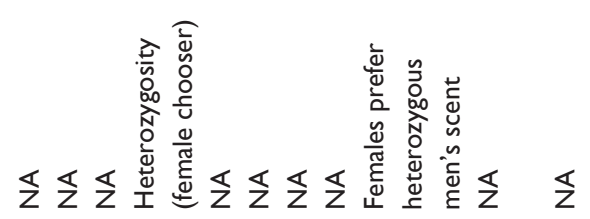

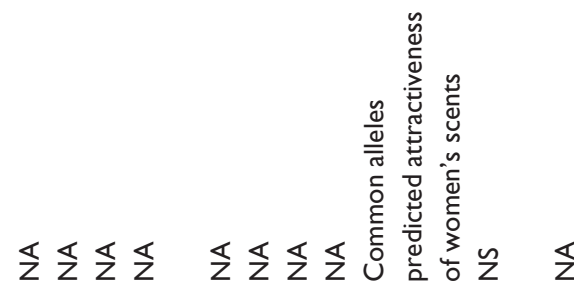

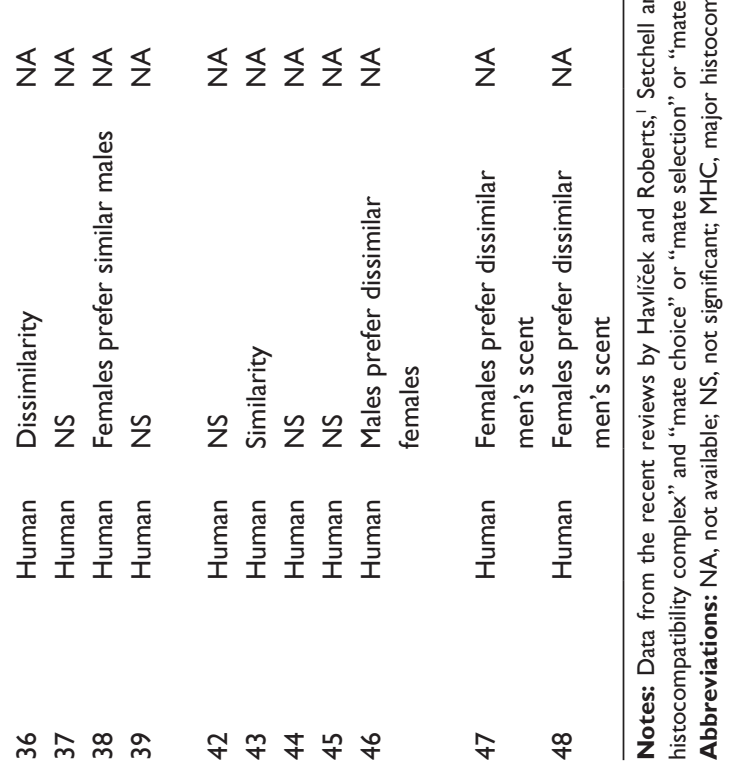

\section{References}

1. Havlíček J, Roberts SC. MHC-correlated mate choice in humans: a review. Psychoneuroendocrinology. 2009;34(4):497-512.

2. Setchell JM, Huchard E. The hidden benefits of sex: evidence for MHCassociated mate choice in primate societies. Bioessays. 2010;32(11): 940-948.

3. Huchard E, Knapp LA, Wang J, Raymond M, Cowlishaw G. MHC, mate choice and heterozygote advantage in a wild social primate. Mol Ecol. 2010;19(12):2545-2561.

4. Huchard E, Baniel A, Schliehe-Diecks S, Kappeler PM. MHCdisassortative mate choice and inbreeding avoidance in a solitary primate. Mol Ecol. 2013;22(15):4071-4086.

5. Sauermann U, Nürnberg P, Bercovitch F, et al. Increased reproductive success of MHC class II heterozygous males among free-ranging rhesus macaques. Hum Genet. 2001;108(3):249-254.

6. Schwensow N, Fietz J, Dausmann K, Sommer S. MHC-associated mating strategies and the importance of overall genetic diversity in an obligate pair-living primate. Evol Ecol. 2008;22(5):617-636.

7. Setchell J, Charpentier M, Abbott K, Wickings E, Knapp L. Opposites attract: MHC-associated mate choice in a polygynous primate. $J$ Evol Biol. 2010;23(1):136-148.

8. Setchell JM, Abbott KM, Gonzalez JP, Knapp LA. Testing for postcopulatory selection for major histocompatibility complex genotype in a semi-free-ranging primate population. Am J Primatol. 2013;75(10): 1021-1031.

9. Yang B, Ren B, Xiang Z, et al. Major histocompatibility complex and mate choice in the polygynous primate: the Sichuan snub-nosed monkey (Rhinopithecus roxellana). Integr Zool. 2014;9(5):598-612.

10. Chaix R1, Cao C, Donnelly P. Is mate choice in humans MHCdependent? PLoS Genet. 2008;4(9):e1000184.

11. Derti A, Cenik C, Kraft P, Roth FP. Absence of evidence for MHCdependent mate selection within HapMap populations. PLoS Genet. 2010;6(4):e1000925.

12. Coetzee V, Barrett L, Greeff JM, Henzi SP, Perrett DI, Wadee AA. Common HLA alleles associated with health, but not with facial attractiveness. PLoS ONE. 2007;2(7):e640.

13. Laurent R, Chaix R. MHC-dependent mate choice in humans: why genomic patterns from the HapMap European American dataset support the hypothesis. Bioessays. 2012;34(4):267-271.

14. Derti A, Roth FP. Response to "MHC-dependent mate choice in humans: why genomic patterns from the HapMap European American data set support the hypothesis" (DOI: 10.1002/bies.201100150). Bioessays. 2012;34(7):576-577.

15. Laurent R, Chaix R. HapMap European American genotypes are compatible with the hypothesis of MHC-dependent mate choice (response to DOI 10.1002/bies. 201200023, Derti and Roth). Bioessays. 2012;34(10):871-872.

16. Garver-Apgar CE, Gangestad SW, Thornhill R, Miller RD, Olp JJ. Major histocompatibility complex alleles, sexual responsivity, and unfaithfulness in romantic couples. Psychol Sci. 2006;17(10): 830-835.

17. Giphart M, D'Amaro J. HLA and reproduction? J Immunogenet. 1983;10(1):25-29.

18. Hedrick PW, Black FL. HLA and mate selection: no evidence in South Amerindians. Am J Hum Genet. 1997;61(3):505-511.

19. Gill T 3rd. HLA and mate choice. Am J Hum Genet. 1998;62(4):985.

20. Weitkamp LR, Ober C. Reply to Gill. Am J Hum Genet. 1998;62(4): 986-987.

21. Beauchamp GK, Yamazaki K. HLA and mate selection in humans: commentary. Am J Hum Genet. 1997;61(3):494.

22. Ihara Y, Aoki K, Tokunaga K, Takahashi K, Juji T. HLA and human mate choice: tests on Japanese couples. Anthropol Sci. 2000;108(2):199-214.

23. Israeli M, Kristt $D$, Nardi $Y$, Klein T. Genetic considerations in human sex-mate selection: partners share Human Leukocyte Antigen but not Short-Tandem-Repeat identity markers. Am J Reprod Immunol. 2014;71(5):467-471. 
24. Jacob S, McClintock MK, Zelano B, Ober C. Paternally inherited HLA alleles are associated with women's choice of male odor. Nat Genet. 2002;30(2):175-179.

25. Wedekind $\mathrm{C}$. The MHC and body odors: arbitrary effects caused by shifts of mean pleasantness. Nat Genet. 2002;31(3):237; author reply 237.

26. McClintock MK, Schumm P, Jacob S, Zelano B, Ober C. Reply to "The MHC and body odors: arbitrary effects caused by shifts of mean pleasantness". Nat Genet. 2002;31(3):237-238.

27. Jin K, Speed T, Thomson G. Tests of random mating for a highly polymorphic locus: application to HLA data. Biometrics. 1995: 1064-1076.

28. Khankhanian P, Gourraud PA, Caillier SJ, et al. Genetic variation in the odorant receptors family 13 and the MHC loci influence mate selection in a multiple sclerosis dataset. BMC Genomics. 2010;11:626.

29. Laurent R, Toupance B, Chaix R. Non-random mate choice in humans: insights from a genome scan. Mol Ecol. 2012;21(3):587-596.

30. Lie HC, Rhodes G, Simmons LW. Genetic diversity revealed in human faces. Evolution. 2008;62(10):2473-2486.

31. Lie HC, Simmons LW, Rhodes G. Genetic dissimilarity, genetic diversity, and mate preferences in humans. Evol Hum Behav. 2010;31(1):48-58.

32. Milinski M, Croy I, Hummel T, Boehm T. Major histocompatibility complex peptide ligands as olfactory cues in human body odour assessment. Proc R Soc Biol Sci Ser B. 2013;280(1755):20122889.

33. Natsch A. A human chemosensory modality to detect peptides in the nose? Proc R Soc Biol Sci Ser B. 2014;281(1776):20131678.

34. Milinski M, Croy I, Hummel T, Boehm T. Reply to A human chemosensory modality to detect peptides in the nose? by A. Natsch. Proc $R$ Soc Biol Sci Ser B. 2014;281(1776):20132816.

35. Nordlander C, Hammarström L, Lindblom B, Smith CE. No role of HLA in mate selection. Immunogenetics. 1983;18(4):429-431.

36. Ober C, Weitkamp LR, Cox N, Dytch H, Kostyu D, Elias S. HLA and mate choice in humans. Am J Hum Genet. 1997;61(3):497-504.

37. Pollack MS, Wysocki CJ, Beauchamp GK, Braun D Jr, Callaway C, Dupont B. Absence of HLA association or linkage for variations in sensitivity to the odor of androstenone. Immunogenetics. 1982;15(6): 579-589.
38. Roberts SC, Little AC, Gosling LM, et al. MHC-assortative facial preferences in humans. Biol Lett. 2005;1(4):400-403.

39. Roberts SC, Little AC, Gosling LM, et al. MHC-heterozygosity and human facial attractiveness. Evol Hum Behav. 2005;26(3):213-226.

40. Stewart-Williams S, Thomas AG. The ape that thought it was a peacock: does evolutionary psychology exaggerate human sex differences? Psychol Inq. 2013;24(3):137-168.

41. Roberts SC, Havlíček J. Humans are dunnocks, not peacocks: on cause and consequence of variation in human mating strategies. Psychol Inq. 2013;24(3):231-236

42. Roberts SC, Gosling LM, Carter V, Petrie M. MHC-correlated odour preferences in humans and the use of oral contraceptives. Proc R Soc Biol Sci Ser B. 2008;275(1652):2715-2722.

43. Rosenberg LT, Cooperman D, Payn R. HLA and mate selection. Immunogenetics. 1983;17(1):89-93.

44. Sans M, Alvarez I, Callegari-Jacques S, Salzano F. Genetic similarity and mate selection in Uruguay. J Biosoc Sci. 1994;26(03):285-289.

45. Santos PSC, Schinemann JA, Gabardo J, da Graça Bicalho M. New evidence that the MHC influences odor perception in humans: a study with 58 Southern Brazilian students. Horm Behav. 2005;47(4):384-388.

46. Thornhill R, Gangestad SW, Miller R, Scheyd G, McCollough JK, Franklin M. Major histocompatibility complex genes, symmetry, and body scent attractiveness in men and women. Behav Ecol. 2003;14(5): 668-678.

47. Wedekind C, Füri S. Body odour preferences in men and women: do they aim for specific MHC combinations or simply heterozygosity? Proc R Soc Biol Sci Ser B. 1997;264(1387):1471-1479.

48. Wedekind C, Seebeck T, Bettens F, Paepke AJ. MHC-dependent mate preferences in humans. Proc R Soc Biol Sci Ser B. 1995;260(1359): 245-249.

49. Hedrick P, Loeschcke V, Boero F. MHC and mate selection in humans? Trends Ecol Evol. 1996;11(1):24.

50. Wedekind C, Seebeck T. MHC and mate selection in humans? Reply. Trends Ecol Evol. 1996;11(1):24-25.
Research and Reports in Biology

\section{Publish your work in this journal}

Research and Reports in Biology is an international, peer-reviewed, open access journal publishing original research, reports, editorials, reviews and commentaries on all areas of biology including animal biology, biochemical biology, cell biology, ecological studies, evolutionary biology, molecular biology, plant science and botany. The

\section{Dovepress}

manuscript management system is completely online and includes a very quick and fair peer-review system. Visit http://www.dovepress. com/testimonials.php to read real quotes from published authors. 